\title{
Evaluation of the potential of biogas generation, of different organic waste, generated in Tabasco
}

\author{
José Aurelio Sosa-Olivier ${ }^{1 *}$, Elyasib Abiam Briseño Flores ${ }^{2}$, Karina Elena \\ Hernández-Pérez ${ }^{2}$, Gerardo Álvarez-Anguloº ${ }^{2}$ Juan Carlos Esquivel Checa- \\ Espinosa $^{2}$, César Gómez Beltrán ${ }^{2}$, José Ramón Laines Canepa ${ }^{1}$

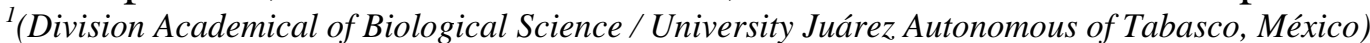 \\ ${ }^{2}$ (Campus Villahermosa/ University of the Valley of México, México)
}

\begin{abstract}
The use of organic waste, as a basis for obtaining renewable energies, is a booming activity in developed areas of the European Union, and Mexico, in specific, the southeast area where Tabasco belongs, is the source of various substrates that can be exploited. The present objective is to determine the analytical characteristics of different substrates generated in the State of Tabasco, and to determine theoretically its potential in obtaining biogas, thermal and electrical energy. The analytical results, indicate that pork and cow excreta, and the water lily, have the highest SVT content, with $82.82 \pm 1.33 \%, 81.41 \pm 1.43 \%$ and $81.19 \pm$ $2.52 \%$ respectively. The theoretical biogas production was higher in pig substrates $\left(20.21 \mathrm{~m}^{3} \mathrm{~d}^{-1}\right)$, chicken $\left(15.73 \mathrm{~m}^{3} \mathrm{~d}^{-1}\right), \operatorname{dog}\left(11.57 \mathrm{~m}^{3} \mathrm{~d}^{-1}\right)$ and lamb $\left(9.25 \mathrm{~m}^{3} \mathrm{~d}^{-1}\right)$. In heat capacity, the chicken and pork substrates, present the highest theoretical capacity in substitution of LP gas with 5.02 and $6.45 \mathrm{~kg} \mathrm{~d}^{-1}$, respectively. Finally, the theoretical values of electricity generation were presented in the substrate chicken, pork and lamb, with 2,156.71, 2,404.37 and 2,475.91 $\mathrm{kW}_{\text {year }}{ }^{-1}$, respectively. With the present work, demonstrates the potential of various substrates in energy production, both heat, as electric.
\end{abstract}

Keywords: Methane, Renewable energy, Substrates, Total volatile solids

\section{Introduction}

Renewable energies in Mexico contribute $15.90 \%$ of electricity generation, the hydroelectricity contributes $12.30 \%$ of the total, followed by geothermal with $2.20 \%$, biomass with $0.85 \%$, wind energy with $0.56 \%$ and photovoltaic solar with $0.01 \%$ (SENER, 2013). With the industrial development, commercial and services, the generation of waste increases directly, nevertheless, the increase in the use of waste is notorious, from its use directly, until its transformation by thermal processes, chemical and biological. on an international level, the use of biomass accounts for two thirds of renewable energy in Europe and bioenergy is expected to play a key role, with which it is intended to supply $20 \%$ of the electricity generated by 2020 , when currently it is 8.5\% (MARM, 2010). Germany in 2012, supported 66\% of energy consumption with the use of biomass, with this occurred $50.2 \%$ of electricity (Gülzow-Prüzen 2013). In Mexico, $137.1 \mathrm{GWh} \mathrm{a}^{-1}$ is generated with the use of biogas, agricultural waste currently generates $1.1 \mathrm{GWh} \mathrm{a}^{-1}$, but has a generation potential of 11,485.00 $\mathrm{GWh}$ (SENER, 2016). Agricultural residues such as crop residues, manures and residues from agro-industrial processes, urban solid waste and special management, of urban character, water and sludge from wastewater treatment plants, are important sources of biomass, which does not always tend to be exploited. Proper management of biomass, manures, has been a problem that impacts the whole society, particularly in public health. Undoubtedly, the livestock sector represents an important source of biomass, but its inadequate management impacts the generation of greenhouse gas emissions (GHG) around the world, the Food and Agriculture Organization of the United Nations (FAO) reports that the livestock sector generates 7.1 giga tons of carbon dioxide per year, with $14.5 \%$ of GHGs being induced by human activity worldwide (Montejo, 2015). Data reported by FAO (2013) indicate that the livestock sector contributes 65\% of GHG emissions in the agricultural sector, with 4.6 giga tons of $\mathrm{CO}_{2}$-eq, activities such as meat production and handling of manures, represent 41 and 20\%, respectively, of GHG emissions. There are important data on gas emissions by species in the livestock sector, the large ruminants (cows, bulls and buffaloes), both in meat and milk production, emit $60 \%$ of GHG from the sector, followed by the production of pigs, with $9 \%$ and chickens $8 \%$ (FAO, 2013). At the national level in 2007, the livestock sector generated 57,842 tones (INEGI, 2007). Tabasco occupies the seventh place in cattle production, with 1'583,656 heads approximately, both in meat and dairy production. It should be noted that the management of excreta represents an important point of attention. It is estimated that some cattle whose average weight is $500 \mathrm{~kg}$, generates approximately $34 \mathrm{~kg}$ of excreta (Posadas et al., 2014). based on what Sánchez (2003) reported, Pino et al. (2012) and SIAP (2014) it can be estimated that in Tabasco $53^{\prime} 844,304 \mathrm{~kg}$ of excreta are generated per day. The DA has been a highly-resorted technique in the production of biogas and digestates, with great potential of use, nevertheless, the quality of these, as well as the times and 
efficiencies of degradation, are influenced by the type of substrate used. Montejo et al. (2015) mention that the potential of the substrate in biogas production, is supported by the physicochemical characteristics that they possess, such as moisture content, total solids (ST), total volatile solids (SVT), fixed solids (SF) and ash. Romero et al. (1997) report that the excreta of horse has values of humidity of $25 \%, \mathrm{pH}$ of 7 and a potassium content of $2.5 \%$ for the case of excreta of lamb, the values are 20\%, 7.2 and 30\%, respectively. Karki et al. (2005) report SVT content of $74.89 \%$ on dry basis, in excreta of lamb. Álvarez and Lidén (2009) obtained biogas with a concentration of $49.90 \%$ of methane, using a mixture with $12.60 \%$ SVT, in excreta of lamb. Sarabia et al. (2015) reports ST and SVT (dry basis) content of 87.49 and $82.12 \%$, respectively, in excreta of lamb. Zhang et al. (2014) report values of $29.96 \pm 0.26 \%$ ST and $20.89 \pm 0.23 \%$ SVT, in pig excreta. Chen et al. (2015) report the use of pig excreta in $\mathrm{AD}$, with a ST content of 20 to $35 \%$ and a production of $2.40 \mathrm{~L} \mathrm{~d}-1$ of biogas, reaching a degradation rate of up to 55.60\%. Montejo et al. (2015) reported a content of $35.16 \pm 2.24 \%$ ST and $20.42 \pm 5.77 \%$ SVT, in pig excreta. García (2009) reports, that excreta of cattle have $83.37 \%$ of SVT. Plant materials have also been used, such as water lily or hyacinth, with values of $33.30 \%$ ST and $82.85 \%$ SVT (Patil et al., 2014), like the vegetable remains, with values of 19.85 and $92.27 \%$, respectively (Prema et al., 1992). There is little information about substrate of domestic animals such as cats, dogs, pigeons and others. Thus, the present work has as general objective, to determine the theoretical potential of biogas production of various organic substrates generated in the state of Tabasco.

II.1 Substrates and analytical characteristics

\section{Method}

Eight substrates were considered based on availability and ease of production, which were excreta of cow, lamb, horse, pigs, chicken and dog, as well as vegetable residues of kitchen and aquatic lily. All the substrates were determined their analytical content, by means of gravimetric tests (loss of weight by variation of temperature), such as the determination of moisture, subjecting samples at $103{ }^{\circ} \mathrm{C}$ for $24 \mathrm{~h}$, based on NMX016-AA-1984 (SEDUE, 1984a), total volatile solids, subjecting pre-dried samples to a muffle oven at $550^{\circ} \mathrm{C}$, based on the NMX-034-AA-2001 (SEDUE, 2001) and ashes, by subjecting dry and pre-calcined samples, at total calcination at $800^{\circ} \mathrm{C}$, based on NMX-018-AA-1984 (SEDUE, 1984b). All determinations were performed in quintuplicate.

\section{II.2 Statistical analysis}

One-factor analysis of variance was performed, to find significant differences of the substrates evaluated, considering its average SVT and Ash content. Likewise, the Tukey multiple test was applied to determine differences between each substrate. For that, the STATGRAPHICS ${ }^{\circledR}$ Centurion XV program was used.

II.3 Theoretical production of methane $\left(\mathrm{CH}_{4}\right)$

To calculate the theoretical volume values of $\mathrm{CH}_{4}$ and biogas, we used the methodology of Sánchez (2003) and Montejo et al. (2015), considering the content of SVT, of a base of $100 \mathrm{~kg}$ per month for each substrate, a temperature of $32{ }^{\circ} \mathrm{C}$ and a hydraulic retention time (TRH) of 30 days.

$$
\begin{aligned}
& K=0.6+0.0006 * e^{(0.1185 * S V T)} \\
& U=0.013+T^{\circ} * 0.129 \\
& V_{C H_{4}=B O} * S V T *\left(1-\frac{K}{U * T R H-1+K}\right)
\end{aligned}
$$

Where:

$\mathrm{V}_{\mathrm{CH} 4}=$ Volume of methane generated $\left(\mathrm{m}^{3} \mathrm{~d}^{-1}\right)$.

$\mathrm{BO}=$ methane production factor $\left(\mathrm{m}_{3} \mathrm{CH}_{4} \mathrm{~kg}^{-1} \mathrm{SVT}\right)$.

$\mathrm{SVT}=$ Total volatile solids content $(\mathrm{kg})$.

$\mathrm{K}=$ decomposition of the volatile solids in time (dimensionless).

$\mathrm{U}=$ Growth of methane production with the change of temperature per day.

$\mathrm{TRH}=$ Hydraulic Retention Time (days).

$\mathrm{e}=$ Constant of Euler.

$\mathrm{T}^{\circ}=$ Average ambient temperature $\left(32^{\circ} \mathrm{C}\right)$.

The BO factors were taken from several authors, as shown in Table 1. 
Table 1. $\mathrm{CH}_{4}$ yields, on various substrates

\begin{tabular}{lll}
\hline Substrates & $\mathrm{BO}\left(\mathrm{m}^{3} \mathrm{CH}_{4} \mathrm{~kg}^{-1} \mathrm{SVT}\right)$ & Author \\
\hline Cow & 0.20 & Sánchez (2003) \\
Lamb & 0.22 & Alvareza y Lidén (2009) \\
Horse & 0.23 & Wartell et al. $(2012)$ \\
Pigs & 0.45 & Sánchez (2003) \\
Chicken & 0.39 & Sánchez (2003) \\
Dog* & 0.45 & - \\
Vegetable waste & 0.55 & Prema et al. (1992); Callaghan \\
Water lily & 0.18 & et al. (2002) \\
ound no BO value, was taken the same of pigs, due to its omnivorous quality.
\end{tabular}

* Note: found no BO value, was taken the same of pigs, due to its omnivorous quality.

To determine the proportion of $\mathrm{CO}_{2}$ that constitutes biogas in a generic way, the theoretical composition of the biogas is considered, $60 \% \mathrm{CH}_{4}$ and $40 \% \mathrm{CO}_{2}$, for this the following equations were used (Sánchez, 2003):

$$
\begin{aligned}
& \text { Quantity of } \mathrm{CH}_{4}=x \frac{\mathrm{m}^{3} \mathrm{CH}_{4}}{\text { day }} \\
& \text { Quantity of } \mathrm{CO}_{2}=\frac{X * 0.40}{0.60}=x \frac{m^{3} \mathrm{CO}_{2}}{\text { day }} \\
& \text { Quantity of biogas }\left(\frac{\mathrm{m}^{3}}{\text { day }}\right)=\frac{m^{3} \mathrm{CH}_{4}}{\text { day }}+\frac{\mathrm{m}^{3} \mathrm{CO}_{2}}{\text { day }}
\end{aligned}
$$

II.4 Gas Substitution calculations L.P.

In the case of the use of biogas, $1 \mathrm{~kg}$ of methane is equivalent to $55 \mathrm{MJ}\left(38 \mathrm{MJ} \mathrm{m}^{-3}\right)$ while $1 \mathrm{~kg}$ of $\mathrm{LP}$ gas is 50 MJ (Sánchez, 2003). Thus, based on the above equivalence, the calorific potential of biogas production was determined, based on the methodology reported by Sánchez (2003):

$$
\begin{aligned}
& \text { Total of MJ to } \mathrm{CH}_{4}=\left(X \frac{\mathrm{m}^{3}}{\text { day }}\right) *\left(38 \frac{\mathrm{MJ}}{\mathrm{m}^{3}}\right)=X \frac{M J}{\text { day }} \\
& \text { Less lost }=\left(X \frac{M J}{\text { day }}\right) *(0.70)=X \frac{M J}{\text { day }} \\
& \text { Equivalence in kg to Gas LP }=\frac{X \frac{M J}{d a y}}{50 \frac{M J}{\mathrm{~kg}}}=X \frac{\mathrm{kg}}{\text { day }}
\end{aligned}
$$

II.5 Theoretical production of electrical energy

The production of electrical energy, was based on the methodology reported by Akbulut (2012), which is described below.

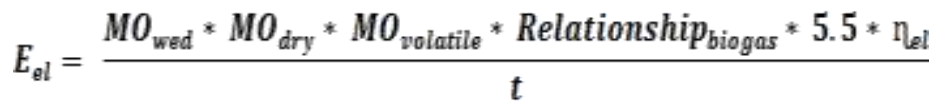

Where:

$\mathrm{E}_{\mathrm{el}}$ : Electric power $(\mathrm{kW})$

$\mathrm{MO}_{\text {wed }}$ : Fresh organic matter

$\mathrm{MO}_{\mathrm{dry}}$ : Organic dry matter

$\mathrm{MO}_{\text {volatile: Volatile matter }}$

Relationship biogas $: 300 \mathrm{~m}^{3} \mathrm{t}^{-1}$ organic material

5.5: total energy factor $\left(\mathrm{kWh} \mathrm{m}^{-3}\right)$

$\eta_{\mathrm{el}}$ : Electricity efficiency value $(40 \%)$

t: Effective hours of the motor-generator per year

For that, an annual production rate was considered, considering $100 \mathrm{~kg}$ of substrates per month $(1.2 \mathrm{t}$ year ${ }^{-1}$ ), as well as an average $8 \mathrm{~h} \mathrm{day}^{-1}$ use of an electrical generation equipment.

\section{Results and Discussion}

In Table 2, the analytical results of each substrate are shown (Figure 1).

Table 2. Mean values of each analytical component, per substrate

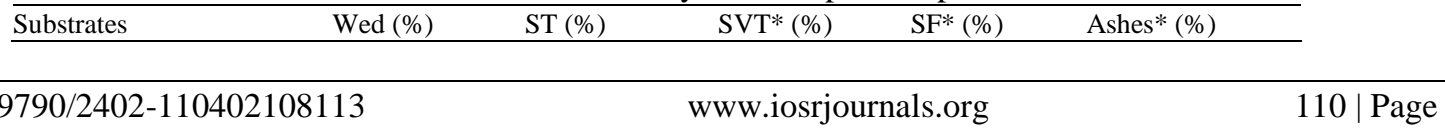




\begin{tabular}{llllll}
\hline Cow & $89.78 \pm 1.21$ & $10.22 \pm 1.21$ & $81.19 \pm 2.52$ & $6.47 \pm 2.42$ & $12.34 \pm 1.08$ \\
Lamb & $90.15 \pm 1.15$ & $9.85 \pm 1.15$ & $76.96 \pm 3.17$ & $11.67 \pm 1.88$ & $11.37 \pm 1.77$ \\
Horse & $60.97 \pm 1.33$ & $39.03 \pm 1.33$ & $66.99 \pm 3.06$ & $8.06 \pm 3.65$ & $24.95 \pm 1.36$ \\
Pigs & $79.60 \pm 0.21$ & $20.40 \pm 0.22$ & $73.07 \pm 2.49$ & $12.54 \pm 0.93$ & $14.39 \pm 1.897$ \\
Chicken & $87.99 \pm 0.32$ & $12.01 \pm 0.32$ & $81.41 \pm 1.43$ & $7.99 \pm 0.69$ & $10.60 \pm 1.05$ \\
Dog & $64.22 \pm 1.07$ & $35.78 \pm 1.07$ & $66.76 \pm 0.90$ & $7.35 \pm 0.54$ & $25.89 \pm 0.46$ \\
Vegetable waste & $64.81 \pm 1.86$ & $35.19 \pm 1.86$ & $82.82 \pm 1.33$ & $5.12 \pm 4.89$ & $12.06 \pm 5.37$ \\
Water lily & $41.51 \pm 22.14$ & $58.49 \pm 22.15$ & $51.31 \pm 10.76$ & $12.02 \pm 4.77$ & $36.68 \pm 14.74$ \\
\hline
\end{tabular}

* Note: dry base

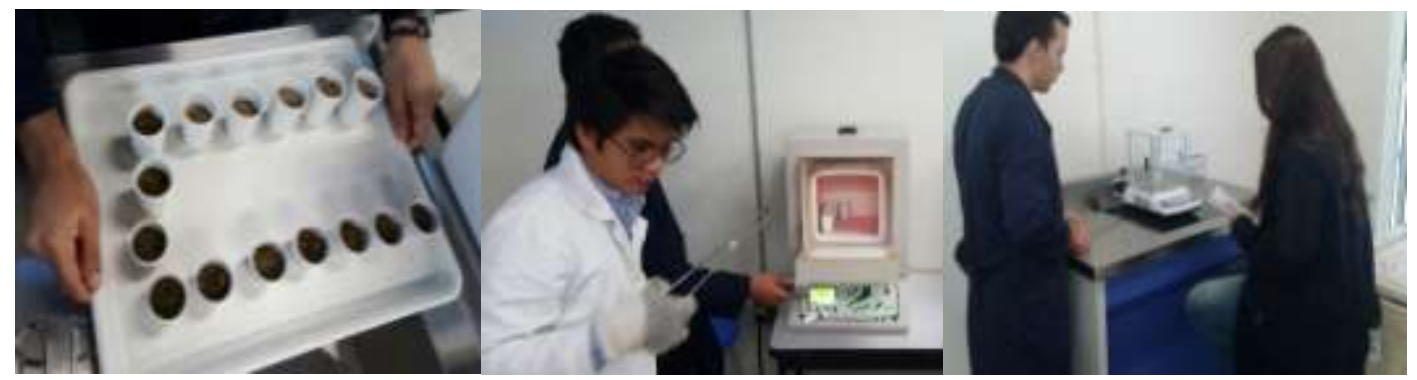

Figure 1. Submission of samples to thermal-gravimetric analytical tests

The moisture content obtained in horse excreta is like that reported by Romero et al. (1997), although it differs in the same parameter with excreta of lamb, being higher than what is obtained in the present. The SVT content in sheep excreta, is slightly lower than that reported by Karki et al. (2005) and Sarabia et al. (2015), the ST content, is like that reported by Chen et al. (2015). SVT values in cattle excreta are like those reported by García (2009). The content of ST and SVT in aquatic lily, is smaller and similar, respectively, as reported by Patil et al. (2014). The ST and SVT are lower than those reported by Prema et al. (1992).

The analysis of variance of one factor, shows that there are significant differences $(P=0.0001)$ between the substrates evaluated, are highlighted as better substrates, the excreta of pork and cow, like water lily and plant residues, which makes them potentially usable in anaerobic digestion processes. The excreta of lamb, are the ones that lower SVT content, presented in this research (Figure 2).

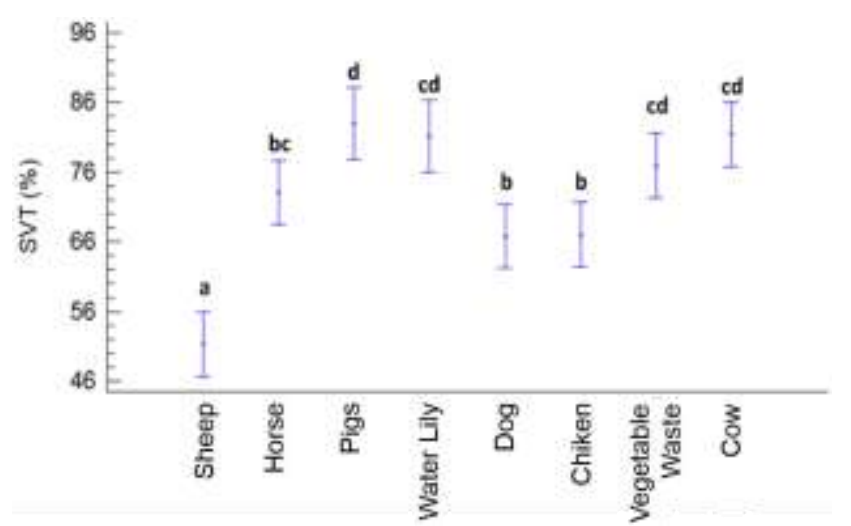

Figure 2. Analysis of variance of SVT content, with standard error.

As for ash content, the analysis of variance of a factor, shows that there are significant statistical differences $(\mathrm{P}=0.0001)$ among the evaluated substrates. Highlighted substrates, excreta of lamb, of dogs and chickens, with the highest ash content (Figure 3). 


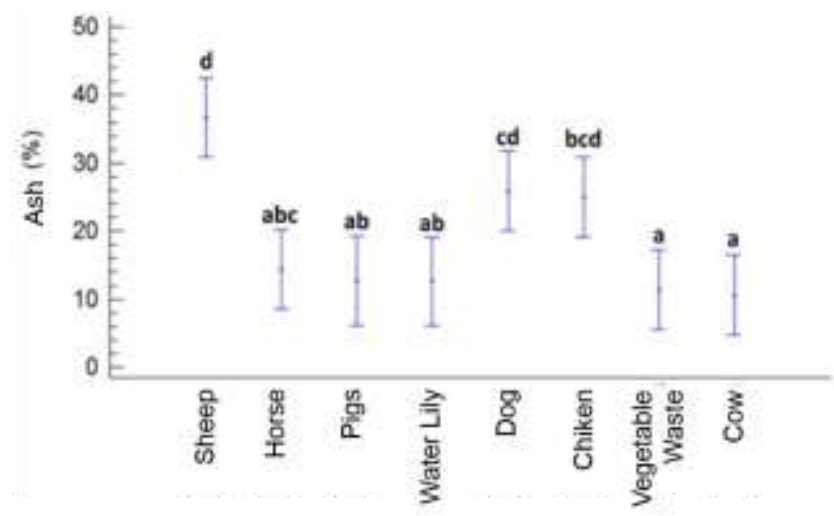

Figure 3. Analysis of variance of the ash content, with standard error.

III.2 Theoretical calculation of methane generation

The theoretical methane production for each of the substrates is shown in Table 3.

Table 3. Theoretical production of $\mathrm{CH} 4$ for each substrate.

\begin{tabular}{lllllllll}
\hline & Acuatic Lily & Vegetable & Chicken & Horse & Cow & Dog & Pig & Lamb \\
\hline ST $(\mathbf{k g})$ & 10.22 & 9.85 & 39.03 & 20.39 & 12.01 & 35.78 & 35.19 & 58.49 \\
SVT $(\mathbf{k g})$ & 8.30 & 7.58 & 26.14 & 14.90 & 9.78 & 23.89 & 29.14 & 30.01 \\
$\mathbf{B O}\left(\mathbf{m}^{\mathbf{3}} \mathbf{~ k g}^{-1} \mathbf{S V T}\right)$ & 0.185 & 0.55 & 0.39 & 0.23 & 0.20 & 0.45 & 0.45 & 0.22 \\
$\mathbf{U}$ & 0.287 & 0.287 & 0.287 & 0.287 & 0.287 & 0.287 & 0.287 & 0.287 \\
$\mathbf{K}$ & 0.602 & 0.601 & 0.613 & 0.604 & 0.602 & 0.610 & 0.619 & 0.621 \\
$\mathbf{V}_{\mathbf{C H 4}}\left(\mathbf{m}^{\mathbf{3}}\right)$ & 2.42 & 2.21 & 9.44 & 4.56 & 1.81 & 6.94 & 12.13 & 5.55 \\
\hline
\end{tabular}

In the above table, it can be noticed that the highest production of $\mathrm{CH}_{4}$ is present in the chicken, horse, dogs, pigs and sheep substrates. It is important to note that the substrates with the highest production of $\mathrm{CH}_{4}$ have a higher content of dry mass, and in turn, of SVT, considering the basic amount of calculation $(100 \mathrm{~kg})$.

In Table 4, the theoretical production of biogas is shown, determining by difference the $\mathrm{CO}_{2}$ content.

Table 4. Production of theoretical biogas daily.

\begin{tabular}{lllllllll}
\hline Volumen $\left(\mathbf{m}^{\mathbf{3}}\right)$ & Acuatic Lily & Vegetable & Chicken & Horse & Cow & Dog & Pig & Lamb \\
\hline $\mathbf{V}_{\mathbf{C H} 4}$ & 2.42 & 2.21 & 9.44 & 4.56 & 1.81 & 6.94 & 12.13 & 5.55 \\
$\mathbf{V}_{\mathbf{C O 2}}$ & 1.61 & 1.47 & 6.29 & 3.04 & 1.21 & 4.63 & 8.09 & 3.70 \\
Biogas & 4.03 & 3.68 & 15.73 & 7.59 & 3.02 & 11.57 & 20.21 & 9.25 \\
\hline
\end{tabular}

In Table 5, the capacity of replacement of LP gas by biogas is shown, considering its daily production and calorific value.

Table 5. Replacement of LP gas by biogas.

\begin{tabular}{lllllllll}
\hline & Acuatic Lily & Vegetable & Chicken & Horse & Cow & Dog & Pig & Lamb \\
\hline $\mathbf{V}_{\mathbf{C H} 4}$ & 2.42 & 2.21 & 9.44 & 4.56 & 1.81 & 6.94 & 12.13 & 5.55 \\
$\mathbf{M J / d}$ & 91.79 & 83.82 & 358.53 & 173.14 & 68.85 & 263.90 & 460.88 & 210.88 \\
$\mathbf{M J / d * ( 0 . 7 )}$ & 64.26 & 58.67 & 250.97 & 121.20 & 48.19 & 184.73 & 322.61 & 147.61 \\
$\mathbf{~ k g / d ~ G a s ~ L P ~}$ & 1.29 & 1.17 & 5.02 & 2.42 & 0.96 & 3.69 & 6.45 & 2.95 \\
\hline
\end{tabular}

It is noteworthy that most of the substrates reach a theoretical substitution greater than $1 \mathrm{~kg}$ of daily LP gas, except the cow substrate being the smallest and the excreta of pig the one of greater substitution. Table 6 shows the theoretical quantities of electricity production on an annual basis, with the use of biogas generated from the daily base amount considered in the beginning.

Table 6. Production of electrical energy by substrate

\begin{tabular}{lllllllll}
\hline Production of electricity & Acuatic Lily & Vegetable & Chicken & Horse & Cow & Dog & Pig & Lamb \\
\hline kW yearly & 684.86 & 625.32 & $2,156.71$ & $1,229.40$ & 806.47 & $1,970.94$ & $2,404.37$ & $2,475.91$ \\
\hline
\end{tabular}

The substrates with greater capacity of production of electrical energy are chicken, pigs and sheep, this is due to the analytical characteristics of each substrate, the amount of ST and SVT of each. 


\section{Conclusion}

Theoretically demonstrates the potential and feasibility of using organic waste generated in the state of Tabasco, representing an option of renewable energy production, especially in rural or sub-urban areas, where it is easily counted with the substrates raised in the present.

\section{Gratitude}

To the students of the UVM campus Villahermosa, of the degree in Engineering in energy and sustainable development, to the students of the course, prospective energetic and bioenergy of the cycle 2-2016, who collaborated in the present work.

\section{References}

[1]. Akbulut A. Techno-economic analysis of electricity and heat generation from farm-scale biogas plant: Çiçekdağı case study. Energy 44(1), $381-390.2012$.

[2]. Álvarez R. y Lidén G. Low temperature anaerobic digestion of mixtures of llama, cow and sheep manure for improved methane production. Biomass Bioenerg. 33, 527-533. DOI:10.1016/j.biombioe.2008.08.012. 2009.

[3]. Alvareza R. y Lidén G. Low temperature anaerobic digestion of mixtures of llama, cow and sheep manure for improved methane production. Biomass and Bioenergy 33(3), 527-533. 2009.

[4]. Callaghan, F.J., Wase, D.A.J., Thayanithy, K., Forster, C.F. Continuous codigestión of cattle slurry with fruit and vegetable wastes and chicken manure Biomass Bioenergy 27 (1), 71-77. 2002.

[5]. Chen, C., Zheng, D., Liu, G. J., Deng, L. W., Long, Y., \& Fan, Z. H. Continuous dry fermentation of swine manure for biogas production. Waste Management, 38. 436-442. 2015.

[6]. FAO, Organización de las Naciones Unidas para la Agricultura y la Alimentación. Enfrentando el cambio climático a través de la ganadería, una evaluación global de las emisiones y oportunidades de mitigación. Roma, Italia, 153 p. 2013.

[7]. Gülzow-Prüzen. Biogas. Bioenergie (Fachagentur Nachwachsende Rohstoffe). Recuperado de: https://mediathek.fnr.de/media/downloadable/files/samples/b/r/brosch-biogas-2013-web-pdf_1.pdf

[8]. Karki A. Shrestha J., Bajgain S. Biogas as renewable source of energy in Nepal: theory and development. Kathmandu, Nepal. Alternative Energy Promotion Center (AEPC), 270 p. 2005.

[9]. MARM, Ministerio del medio ambiente y medio rural y marino. "El sector del biogás agroindustrial en españa." Direccion general de recursos agrícolas y ganaderos (Ministerio del medio ambiente y medio rural y marino). 2010.

[10]. Montejo S., Laines J. Sosa J. Hernández L. y Ávila I. Estudio de generación y cálculo del potencial de biogás en la granja porcina de la División Académica de Ciencias Agropecuarias - UJAT. Kuxulkab’21(40), 45 - 50. 2015.

[11]. NMX-016-AA-1984 (1984). Secretaría DE Desarrollo Urbano y Ecología. Protección al ambiente-contaminación del suelo-residuos sólidos municipales-determinación de humedad.

[12]. NMX-018-AA-1984 (1984). Secretaría DE Desarrollo Urbano y Ecología. Protección al ambiente-contaminación de suelo residuos

[13]. NMX-034-AA-2001 (2001). Secretaría DE Desarrollo Urbano y Ecología. Determinación de sólidos y sales disueltas en aguas naturales, residuales y residuales tratadas.

[14]. Patil J., MAL A., Shankar BB., Kumar M., Kumar P. Anaerobic Co-Digestion of Water Hyacinth and Sheep Waste. Energy Procedia 52, 572 - 578. 2014.

[15]. Pino J., García J. Peña L., Rendón J., González C., y Tristán F. Impactos y regulaciones ambientales del estiércol generado por los sistemas ganaderos de algunos países de América. Agrociencia 46, 359-370. 2012.

[16]. Posadas R., Salinas J., Callejas N., Álvarez G., Herrera J., Arriaga C., Martínez F. Análisis de costos y estrategias productivas en la lechería de pequeña escala en el periodo 2000-2012. Contaduría y Administración (59) 2. Pp. 253- 275. 2014.

[17]. Prema S. Sumithra D. y Krishna N. 2012. Anaerobic Digestion of Fruit and Vegetable Processing Wastes for Biogas Production. Bioresource Technology 40, 43-48.

[18]. Sánchez, S. (2003). Energías renovables, conceptos y aplicaciones. Biomasa. WWF, Quito Ecuador. 150 p. 2003.

[19]. SENER, Secretaria de Energía. Prospectiva de Energías Renovables 2013-2027. Recuperado de: https://www.gob.mx/cms/uploads/attachment/file/62948/Prospectiva_de_Energ_as_Renovables_2013-2027.pdf

[20]. SENER, Secretaria de Energía. Prospectiva de Energías Renovables 2016-2030. Recuperado de: https://www.gob.mx/cms/uploads/attachment/file/177622/Prospectiva_de_Energ_as_Renovables_2016-2030.pdf

[21]. SIAP, Servicio de Información Agroalimentaria y Pesquera. Tabla de población ganadera (porcina). 2014. Recuperado de: http://www.gob.mx/cms/uploads/attachment/file/166003/porcino.pdf

[22]. sólidos municipales determinación de cenizas.

[23]. Wartell B., Krumins V., Alt J., Kang K., Schwab B., Fennell D. Methane production from horse manure and stall waste with softwood bedding. Bioresource Technology 112. 42 - 50. 2012

[24]. Zhang W., Lang Q., Wu S., Li W., Bah H., Dong R. Batch anaerobic co-digestion of pig manure with dewatered sewege sludge under mesophilic conditions. Bioresorurce Technology, 156. 63-69. 2014. 